\title{
LOŠTICKÁ KERAMIKA Z ARCHEOLOGICKÉHO VÝZKUMU BRNĚNSKÉHO HRADU ŠPILBERKA
}

\author{
ZDEŇKA MĚCHUROVÁ
}

\begin{abstract}
Abstrakt: Loštické poháry i hrnce, vyráběné v severomoravských Lošticích u Mohelnice, byly velmi oblíbené pro svůj témér neprosákavý materiál podobný kamenině a puchýrkovitý vzhled povrchu. Jejich produkce spadá do obdobi konce 14. a dále do 15. a 16. století. Podle nových přirodovédných rozborů $i$ experimenti̊ bylo tajemství tohoto materiálu v jílovité hrnčírské hmotě se záměrným pridáváním granátu (pyropu či almandinu). Loštické poháry patřily $k$ vyhledávanému a oblíbenému stolnímu nádobi dokonce i za hranicemi českých zemí.

Při archeologickém výzkumu Špilberka bylo ziskáno ze tři poloh (severni kř́dlo, severovýchodní rohová věžice, jižní kř́ldlo) celkem 88 zlomků loštické keramiky, 53 fragmentů hrncovitých pohárů, 28 střepủ hrnců, z toho jedinýs uchem pod hrdlem, a jeden středový zlomek zvoncovité poklice s knoflikovitou úchytkou. Datování je dáno keramickými typy do starši fáze loštické keramiky, a to na konec 14. a spíše první polovinu 15. století. Ve věžici a severním kř́dle převažuji picí nádoby, hrncovité poháry, zatímco vjižním kř́dle byly nalezeny pouze zlomky loštické kuchyňské keramiky, hrnců. Je otázkou rozboru dalšího materiálu, zda je na takovém základě možno usuzovat na provozni zaměrení zkoumaných prostor, napr. na občasné stolování špilberských strážců v severních prostorách a existenci zásobnich či skladovacích místnostív křidle jižním.
\end{abstract} Klíčová slova: loštická keramika - hrad Špilberk-poháry a hrnce.

\section{Loštice Pottery from Archaeological Research into Špilberk Castle, Brno}

Abstract: Beakers and pots made in the town of Loštice, near Mohelnice in northern Moravia were very popular for their virtually impenetrable material resembling stoneware, with a "blistery" surface. They were produced in the late 14th century, in the 15th century and in the 16th century. According to recent scientific analyses and experiments, the secret of the material lay in the clay body into which garnet (pyrope or almandine) was added. Loštice beakers belonged with sought-after and popular tableware, even outside the Czech lands.

Excavations at Špilberk Castle conducted in three locations (north wing, NE corner tower, south wing) have yielded the total of 88 fragments of Loštice pottery, 53 fragments of pot-shaped beakers and 28 pot sherds that included a fragment with a handle below the neck and a central fragment of a bell-shaped lid with a button-shaped fitting. The dating was derived from the pottery types, and the origin of the products is sought in the early phase of Loštice pottery, i.e. the late 14th century and the first half of the 15th century. In the tower and the north wing drinking vessels and pot-shaped beakers prevailed, while the south wing only yielded fragments of Loštice kitchenware and pots. Further analyses will show whether it is possible, on the basis of this information, to determine the purpose of the investigated premises, for example, an occasional dining place of Špilberk guards in the case of the north wing, and storage rooms in the case of the south wing.

Key words: Loštice pottery - Špilberk Castle-beakers and pots.

\section{Úvod}

Loštické zboží patř́i bezesporu k nejzajímavějším skupinám keramiky vůbec a ve středověku zvláště. Hrnčířské výrobky, poháry i hrnce, vyráběné v severomoravských Lošticích u Mohelnice, byly velmi oblíbené pro svůj téměř neprosákavý materiál podobný kamenině a puchýřkovitý vzhled povrchu. Jejich produkce spadá do období konce 14. a dále do 15. a 16. století. Podle nových př́rodovědných rozborů i experimentů bylo tajemství tohoto materiálu v jílovité hrnčířské hmotě $\mathrm{s}$ přísadou jemného grafitu a hlavně v záměrném přidávání granátu - pyropu či almandinu. Nádoby loštičtí hrnčíři přetahovali speciální glazurou z plaveného cihlářského jílu a železité hlinky pro získání nafialovělého vzhledu. Teplota výpalu byla poměrně vysoká - kolem 1200 stupňů, při ní se krystalky granátu vytavily, způsobily zmíněné bubliny, a tak byl získán požadovaný rozpraskaný puchýřkovitý povrch (Gregerová a kol. 2010, 158-159). Tvar pohárů se vyvíjel od jednoduchých hrncovitých typů po formu s věncem oušek pod okrajem, jejichž počet 
dosahoval až sedmnácti, a to už měly ryze dekorativní účel. Loštické poháry patřily k vyhledávanému a oblíbenému stolnímu nádobí dokonce i za hranicemi českých zemí (Goš 2012, 12-17). Exemplář s dvanácti oušky s pozlacenou pokličkou, na nožce ze stejného kovu je uložen ve sbírkách Muzea užitého umění v Budapešti jako součást pokladu šlechtické rodiny Esterházy z korvínovské éry (druhá polovina 15. a první polovina 16. století; Drobná 1957, 103). Že povědomost o tomto zboží sahala i do západní Evropy, dokazuje zachycení loštického poháru na obraze Hieronyma Bosche Zahrada rajských pokušení z počátku 16. století (Michna 1976, 334; Togner 1995).

\section{Dějiny bádání}

Z výše uvedeného je tedy více než pochopitelné, že specifičnost této skupiny středověké keramiky velmi záhy vzbudila zájem sběratelů i odborníků. Za objevitele lze označit stavitele K. Hladiše z Loštic (r. 1874) a olomouckého profesora J. Havelku (r. 1876), kteří poprvé v Lošticích při výkopech tuto keramiku nalezli. Diskuse o ní se rozpoutala především v německém odborném tisku (jmenujme takové osobnosti jako R. Virchow či J. Wankel - viz podrobněji Drobná 1957, 98-99 - pozn. 5, 6; Lang 1961, 62 - pozn. 1-2). Z moderních věd to byly ovšem dějiny umění, jež specifická keramika zaujala jako první (Drobná 1957, 98-107); regionální historie nedala na sebe dlouho čekat (Lang 1961, 54-62), ale z archeologického pera se loštická keramika dočkala zpracování až koncem 60. let (Nekuda-Reichertová 1968, 150-155; Měřínský 1969, 89-105). V 70. a 80. letech byl obnoven týmový zájem o tuto keramickou skupinu z hlediska způsobu její výroby (Goš 1973, 371-379; Goš-Novák-Karel 1975, 97-105; Goš-Novák 1976, 399-404; Goš 1980, 85-100; 1982, 157-162). V 90. letech pokračovalo hledání př́íčiny jejího specifického vzhledu na nálezech z Konůvek (Měchurová 1989, 217-228; Měchurová-Zalabák-Čejka 1992, 201-215), ale důkladného probádání pomocí přírodovědných analýz a experimentálních počinů se jí dostalo až koncem prvního desetiletí 21. století (Gregerová a kol. 2010, 154-174) za finančního přispění samostatného grantového projektu. Díky tomu se podařilo odhalit složení hmoty a příčinu puchýřovitého vzhledu $\mathrm{v}$ př́ísadách almandinu a granátu. Totéž desetiletí přineslo i archeologické zpracování loštické keramiky a zhodnocení archeologických výzkumů v Lošticích v samostatné monografii, a to populární formou přístupnou široké veřejnosti (Goš 2007).

Archeologie středověku se ovšem práva na objevy loštické keramiky ve svém materiálu nevzdává (např. Bláha-Frolík-Sigl 2003, 525-537); ve starých muzejních sbírkách i nových přírůstcích ze záchranných archeologických výzkumů se „loštická“ alespoň v malé míre objevuje (svou typickou hmotou dobře rozpoznatelná), což znovu potvrzuje oblibu a rozšíření tohoto zboží ve středověku. Není proto divu, že se tento kvalitní keramický materiál vyskytuje i v archeologických vrstvách brněnského hradu Špilberka.

\section{Rozbor materiálu}

Základními typy loštické keramiky jsou loštické hrnce (hrubé, větší, s masivním manžetovitým okrajem), loštické poháry (hrncovité a vyšši štíhlé) a loštické poháry s oušky (dvojí varianty - a) úzké a štíhlé, b) širší a nízké (Nekuda-Reichertová 1968, 151). Typologii propracoval Z. Měřínský (1969, 89-105) a vybavil názornými typologickými i chronologickými obrazovými tabulkami. Není důvod toto jednoduché třídění měnit, a tak slouží dosud (Goš 2007, 66).

Pár slov k terminologii. Okraje loštické keramiky byly již v počátcích bádání o nich nazývány jako manžetovité (Drobná 1957, 99-101), i když se vlastně podobají okruží. Pro okraje hrnců se užívají různé názvy - manžetovitý (Měřínský 1969, 89-90; Šaurová 1971, 180; 1980, 104-105), límcovitý (Goš 1976, 402), římsovitý (Goš 2007, 15), ale v podstatě jde rovněž o určitý druh masivního vysokého okruží se zesíleným ukončením (Měchurová 1989, 217). Ačkoli jsem se původně klonila k tomuto označení, přece jen pro terminologickou přehlednost a jasné odlišení bych použila u hrnců termín okraj manžetovitý. Zdá se ostatně, že se ani v nové literatuře jednotný název pro okraje hrnců neuchytil, tudíž se snad nedopustíme žádné fatální terminologické chyby návratem k původnímu pojmenování. Ovšem pro okraje poháru typu I je vhodné použít 
opravdu termín okruží, což akceptuje i V. Goš $(2007,66)$ v posledním a uceleném zpracování loštického materiálu. Poháry typu II pak mají okraj válcovitý či válcovitý dovnitř zatažený (IIA, resp. IIB; Měřínský 1969, 91). V našem případě budeme pracovat s názvem okruží zcela oprávněně, protože se typologicky budeme pohybovat pouze mezi poháry typu I.

Výzkum z roku 1985 v prostoru severního traktu hradu Špilberka (zv. severní kř́dlo) prováděly archeoložky Muzea města Brna Dana Cejnková a Irena Loskotová. Nálezy pocházejí z homogenizované vrstvy sahající od novověké podlahy po skalní podloží v hloubce ca $300 \mathrm{~cm}$. Jde o zásyp vytvořený při opakovaných stavebních úpravách v prostoru parkánu v průběhu 15. a 16. století, keramika zde nalezená představovala blíže nestratifikovaný terciární odpad datovatelný od poloviny 14 . do 16 . století. ${ }^{1}$

V souboru máme 25 zlomků loštické keramiky (4 ks neurčitelné, inv. č. 321.896-321.914tvrdý výpal fialové barvy, inv. č. 318.615-318.619 - slabý až stř̌ední výpal). Ve většině případů jde o loštické hrncovité poháry typu IA i IB, jak je označil Z. Měŕínský (1969, 90-91, 95 tab. I.) - 19 ks (v 10 případech zlomky dna a dolní výdutě, 3 zlomky okrajů, 6 výdutí) a dva kusy loštických hrnců, jeden je opatřen plochým páskovým uchem na podhrdlí (inv. č. 321.912, obr. 2b), uzpůsobený tak zjevně $\mathrm{k}$ prrenášení obsahu, čímž se řadí $\mathrm{k}$ nejzajímavějším exemplářům v souboru. Z výčtu plyne, že převažují picí, tedy stolní nádoby nad kuchyňskými. Evidentně starší typy zde zastoupené loštické keramiky (hrncovité poháry a hrnce) udávají chronologickou rovinu, a to od konce 14. do konce první poloviny 15. století. Datování zcela koresponduje s časovým zařazením mohutné blíže nečleněné vrstvy.

Věnujme se některým méně typickým kusům. Takovým je inv. č. 318.619 (obr. 1), jehož okraj přesahuje běžný průměr, má ca $13 \mathrm{~cm}$. Materiál je slabě vypálený, světlé šedavé barvy; oběma těmito znaky se blíží kategorii hrnců. Podle tabulky Z. Měř́nského (1969, 95 - tab. I.) je také rozdíl mezi oběma typy minimální, rozhodující je výška nádoby, kterou u fragmentu okraje s horní částí výdutě nelze odhadnout dostatečně přesně.

Ostatní zlomky okrajů pohárů mají průměr ca $10 \mathrm{~cm}$ (např. inv. č. 321.896, obr. 2a) a další

\begin{tabular}{|c|c|c|c|}
\hline typ nádoby & SV rohová věžice & S křídlo & $\mathrm{J}$ křídlo \\
\hline hrnce & 20 & 1 & 7 \\
\hline okraj & 9 & 0 & 1 \\
\hline dno & 4 & 0 & 3 \\
\hline výdut' & 7 & 0 & 3 \\
\hline hrnec s uchem & 0 & 1 & 0 \\
\hline poháry & 34 & 19 & 0 \\
\hline okraj & 11 & 3 & 0 \\
\hline dno & 13 & 10 & 0 \\
\hline výdut' & 10 & 6 & 0 \\
\hline poklice & 1 & 0 & 0 \\
\hline neurčitelné & 1 & 4 & 0 \\
\hline celkem & 56 & 25 & 7 \\
\hline
\end{tabular}

Tab. 1. Nálezy loštické keramiky v areálu hradu Špilberka. Tab. 1. Funde Loschitzer Keramik vom Areal der Burg Spielberg. průměr u velmi drobného fragmentu nelze určit vůbec (inv. č. 321.897).

Průměr den se pohybuje od 5 do $8 \mathrm{~cm}$, nejčastěji je ovšem $6 \mathrm{~cm}$ (6 kusů, obr. 3), dna nesou stopy většinou lasturovitého odříznutí, materiál je tvrdě pálený až fialové barvy na povrchu. Zlomek s inv. č. 318.615 (obr. 3d) má průměr dna s podsýpkou ca $9 \mathrm{~cm}$, výpal je spíše střední, a tedy i v tomto př́ípadě jde o typ na hranici mezi hrncem a hrncovitým pohárem.

Zaměřme se nyní na výzkum z let 1987$1988 \mathrm{v}$ prostoru parkánu u severovýchodni rohové věžice hradu Špilberka. Nálezy pocházejí z homogenizované vrstvy sahající od hloubky $170 \mathrm{~cm}$ až po skalní podloží (místy v hloubce až $700 \mathrm{~cm}$ ). Jde o zásyp vytvořený při opakovaných stavebních úpravách prostoru parkánu v průběhu 15. a 16. století, keramika zde nalezená představovala opět blíže nestratifikovaný terciární odpad datovatelný od poloviny 14. do 16. století.

1 Za poskytnutí materiálu a nálezových okolností děkuji vedoucímu archeologického oddělení Muzea města Brna PhDr. Petru Vachůtovi. 


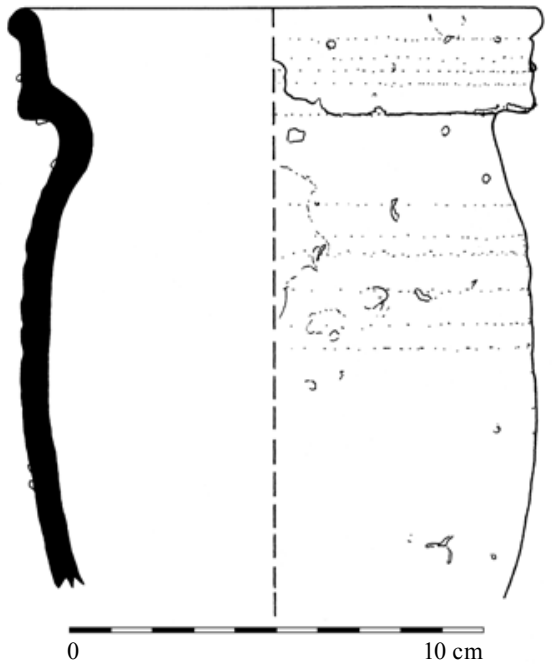

Obr. 1. Špilberk - severní křídlo. Loštický hrnec (?), inv. č. 318.619. Kresba S. Doleželová, počítačová úprava T. Janků. Abb. 1. Spielberg - Nordflügel. Loschitzer Topf (?), Inv.Nr. 318.619. Zeichnung S. Doleželová, digitale Aufbereitung T. Janků.
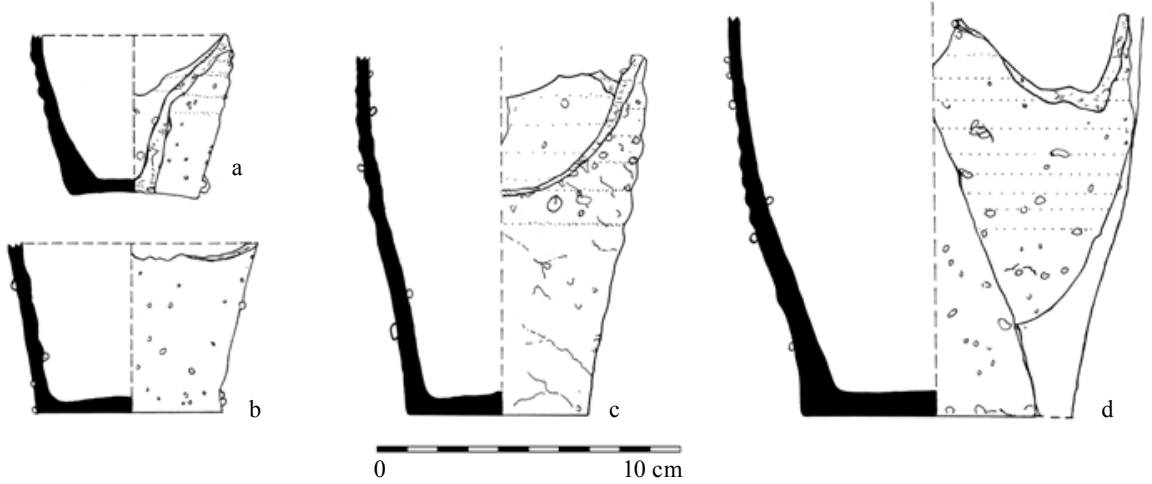

Obr. 3. Špilberk - severní kř́dlo. Dolní výdutě a dna loštických nádob. a -inv. č. 318.615, b - inv. č. 318.617, c - inv. č. 321.903, d -inv. č. 321.905. Kresba S. Doleželová, počítačová úprava T. Janků.

Abb. 3. Spielberg - Nordflügel. Untere Bauchpartien und Böden von Loschitzer Gefäßen. a - Inv.-Nr. 318.615, b - Inv.-Nr. 318.617, c-Inv.-Nr. 321.903, d - Inv.-Nr. 321.905. Zeichnung S. Doleželová, digitale Aufbereitung T. Jankủ.

Soubor čítá 56 zlomků loštické keramiky ( 34 ks z pohárů - z toho 11 okrajů, 13 den a 10 výdutí, $20 \mathrm{ks} \mathrm{z} \mathrm{hrnců} \mathrm{-} \mathrm{z} \mathrm{toho} 9$ okrajů, 7 výdutí a 4 dna hrnců, 1 neurčitelný; inv. č. $326.380-$ 326.397 - tvrdý výpal fialové barvy, 326.399-326.419 - slabý výpal, 326.399-326.401, 326.412 tvrdý výpal). Dvě třetiny tvoří hrncovité poháry, picí a stolní nádoby (obr. 6, 7a, b), zbylou třetinu tvoř́i loštické hrnce, tedy kuchyňská a zásobní keramika (obr. 5c, 7c). Inv. č. 326.419 má jako jediný okraj pro loštické hrnce netypický tvar, a to masivní ovalený (obr. 4c), ostatní jsou klasicky vyšší či nižší manžetovité (obr. 4b, 5c). Inv. č. 326.412 představuje zlomek tvrdě vypálené loštické poklice, konkrétně její středovou část s drobným lasturovitě odříznutým knoflíkem o průměru $3 \mathrm{~cm}$ (obr. 4b). Loštické poklice datuje Z. Měřínský (1969, 93, 95 - tab. I., 104) do první i druhé poloviny 15 . století, jde však o poklice unikátního tvaru, s válcovým pláštěm či napodobující hradní architekturu. V našem př́ípadě jde o zlomek klasické zvoncovité poklice, byt' provede- 


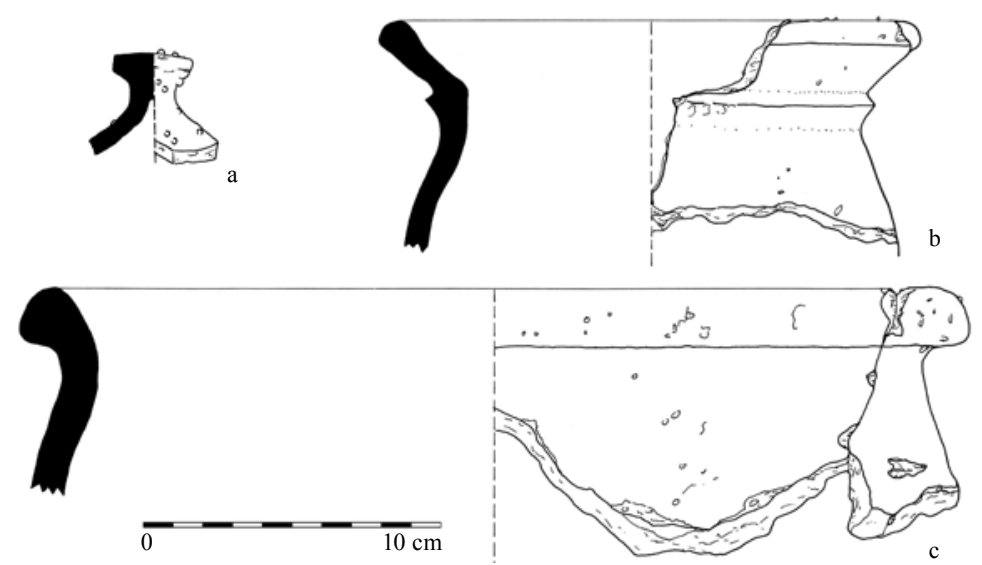

Obr. 4. Špilberk - severovýchodní věžice. a - knoflíkovité držadlo pokličky, inv. č. 326.412, b - okraj hrnce, inv. č. 326.416, c - ovalený okraj zásobního hrnce, inv. č. 321.419. Kresba S. Doleželová, počítačová úprava T. Jankủ.

Abb. 4. Spielberg - nordöstlicher Schalenturm. a - knopfartiger Deckelgriff, Inv.-Nr. 326.412, b - Topfrand, Inv.-Nr. 326.416, c-Randwulst eines Vorratstopfes, Inv.-Nr. 321.419. Zeichnung S. Doleželová, digitale Aufbereitung T. Janků.
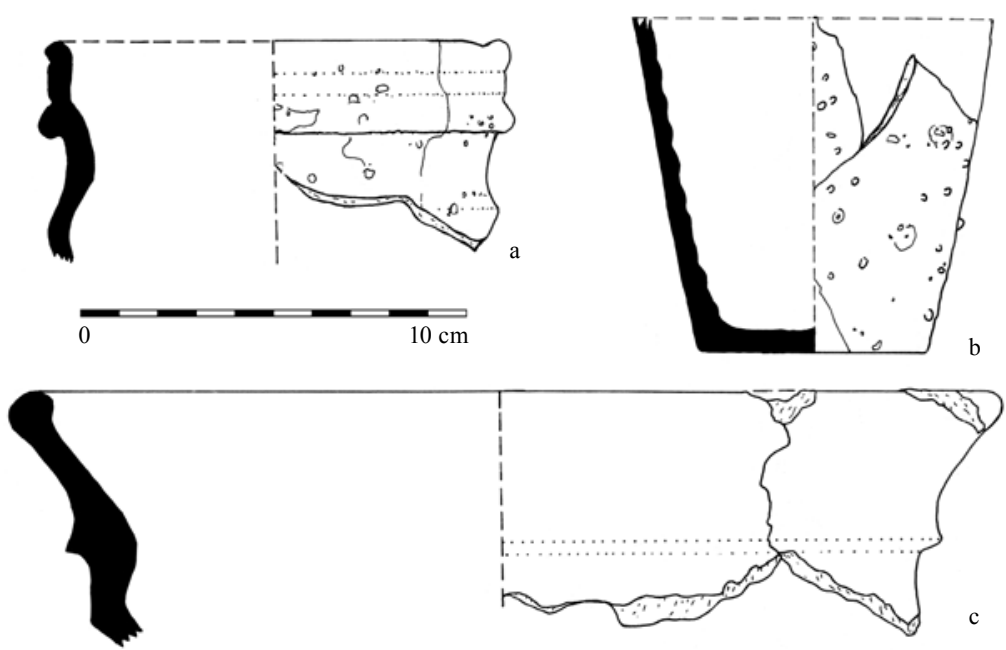

Obr. 5. Špilberk - severovýchodní věžice. a - okraj hrncovitého poháru, inv. č. 326.383, b - dolní část výdutě poháru, inv. č. 326.392, c-manžetovitý okraj zásobního hrnce, inv. č. 326.397. Kresba S. Doleželová, počítačová úprava T. Janků.

Abb. 5. Spielberg - nordöstlicher Schalenturm. a - Rand eines topfartigen Bechers, Inv.-Nr. 326.383, b - unterer Bauchteil eines Bechers, Inv.-Nr. 326.392, c - manschettenartiger Rand eines Vorratstopfes, Inv.-Nr. 326.397. Zeichnung S. Doleželová, digitale Aufbereitung T. Janků.

né v loštickém materiálu, patřící pravděpodobně na ústí hrncovitého poháru (inv. č. 326412, obr. 4a). Tento běžný typ poklice řadí V. Goš $(2007,111$ - obr. 37) zhruba k roku 1450.

Výzkum Aleše Navrátila z let 2011-2013 na jižním křidle prověřil zásyp jižního parkánu hradu, vytvořený v souvislosti se stavebními úpravami hradu někdy v průběhu 15. století (zjištěné vrstvy 109, 130-131 bez přsesnější datace).

Z této polohy pocházejí pouze loštické hrnce, které představují evidentně kuchyňský a skladovací sortiment, a to 7 zlomků, z toho jen 1 střep z okraje (obr. 8a), 3 střepy ze dna (obr. 8b), 2 zlomky dolní výdutě a 1 fragment výdutě obecně (inv. č. 458.215-450.217 - sonda JK008, vrstva 130-131, inv. č. 458.083, 458.084-458.086, sonda JK008, vrstvy 109, 131). Pokud lze z těchto zlomků soudit, jde o části hrnců bez uch, materiál je slabě vypálený šedobéžového 
zbarvení, dna s podsýpkou. Datovány jsou od poslední čtvrtiny 14. století (Nekuda-Reichertová 1968, 151) do první poloviny 15. století (Měŕínský 1969, 103-104).

\section{Závěr}

Při archeologickém výzkumu brněnského hradu Špilberka bylo získáno ze tř́i poloh (severní křídlo, severovýchodní rohová věžice a jižní křídlo) celkem 88 zlomků loštické keramiky: 53 fragmentů hrncovitých pohárů, 28 střepů hrnců ( $\mathrm{z}$ toho jediný s uchem pod hrdlem) a jeden středový zlomek zvoncovité poklice s knoflíkovitou úchytkou. Nálezové okolnosti zásypových vrstev neupřesňují datování, které je dáno keramickými typy do starší fáze loštické keramiky, a to na konec 14. a do 15. století, spíše jeho první poloviny. Ve věžici a severním křídle převažují picí nádoby, hrncovité poháry, zatímco v jižním kř́ídle byly nalezeny pouze zlomky loštické kuchyňské keramiky, hrnců. Je otázkou rozboru dalšího materiálu, zda je na takovém základě možno usuzovat na provozní zaměření zkoumaných prostor, například na občasné stolování špilberských strážců v severních prostorách a existenci zásobních či skladovacích místností v křídle jižním.

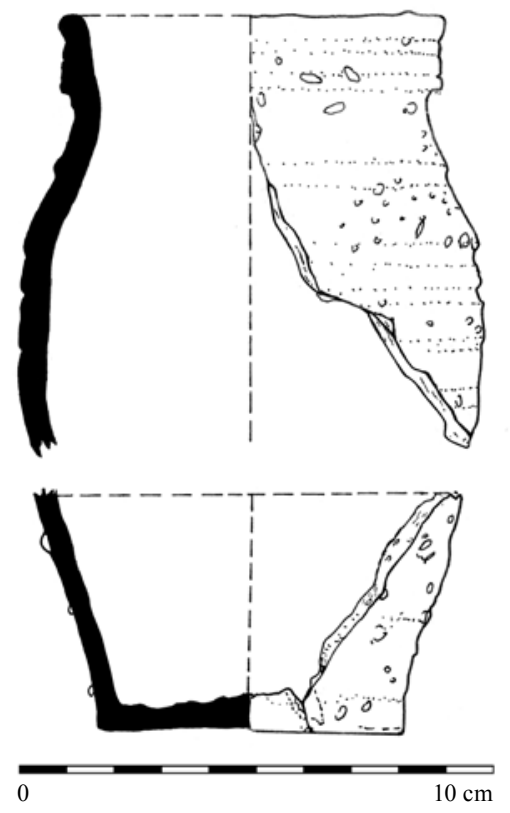

Obr. 6. Špilberk - severovýchodní věžice. Rekonstrukce hrncovitého poháru, inv. č. 326.400. Kresba S. Doleželová, počítačová úprava T. Janků.

Abb. 6. Spielberg - nordöstlicher Schalenturm. Rekonstruktion eines topfartigen Bechers, Inv.-Nr. 326.400. Zeichnung S. Doleželová, digitale Aufbereitung T. Janků.

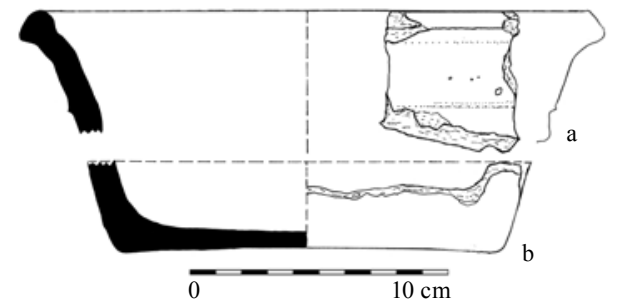

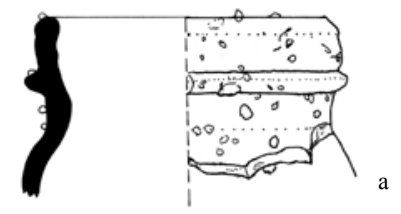
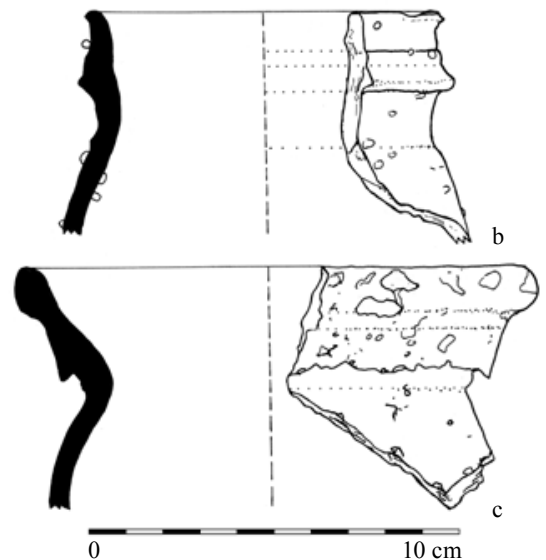

Obr. 7. Špilberk - severovýchodní věžice. a - okraj hrncovitého poháru, inv. č. 326.404, b - okraj hrncovitého poháru, inv. č. 326.405, c - manžetovitý okraj hrnce, inv. č. 326.414. Kresba S. Doleželová, počítačová úprava T. Janků.

Abb. 7. Spielberg - nordöstlicher Schalenturm. a - Rand eines topfartigen Bechers, Inv.-Nr. 326.404, b - Rand eines topfartigen Bechers, Inv.-Nr. 326.405, c - manschettenartiger Rand eines Topfes, Inv.-Nr. 326.414. Zeichnung S. Doleželová, digitale Aufbereitung T. Janků.

Obr. 8. Špilberk - jižní kř́ídlo. a - manžetovitý okraj zásobního hrnce, inv. č. 458.215, b - část dna zásobního hrnce, inv. č. 458.217. Kresba $S$. Doleželová, počítačová úprava T. Janků. Abb. 8. Spielberg - Südflügel. a - manschettenartiger Rand eines Vorratstopfes, Inv.-Nr. 458.215, b - Bodenteil eines Vorratstopfes, Inv.-Nr. 458.217. Zeichnung S. Doleželová, digitale Aufbereitung T. Janků. 


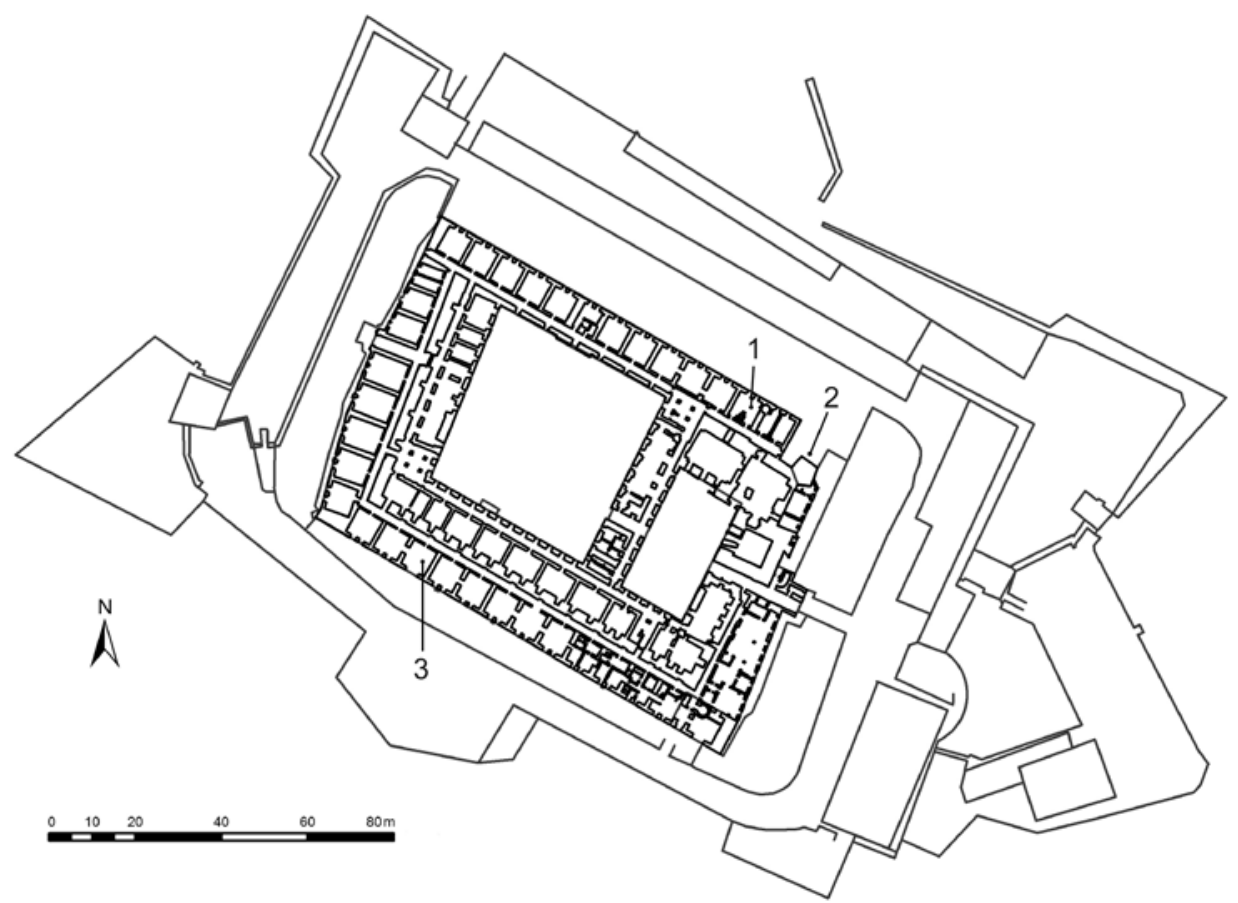

Obr. 9. Špilberk. Archeologické sondy s nálezy loštické keramiky v areálu hradu. 1 - severní kř́́dlo, 2 - severovýchodní věžice, 3 - jižní křídlo. Vyhotovili P. Vachůt, A. Navrátil, Muzeum města Brna.

Abb. 9. Spielberg. Archäologische Sondiergrabungen mit Funden von Loschitzer Keramik auf dem Burggelände: 1 - Nordflügel, 2 - Nordöstlicher Schalenturm, 3 - Südflügel. Erstellt von P. Vachủt, A. Navrátil, Museum der Stadt Brno.

Předložená práce vznikla za finanční podpory Ministerstva kultury ČR v rámci institucionálního financování na dlouhodobý koncepční rozvoj výzkumné organizace Moravské zemské muzeum (DKRVO, MK000094862).

Der vorliegende Artikel entstand mit finanzieller Unterstützung seitens des Kulturministeriums der Tschechischen Republik im Rahmen der institutionellen Finanzierung der langfristigen konzeptionellen Entfaltung der Forschungsinstitution (Mährisches Landesmuseum, MK000094862).

\section{Literatura}

BLÁHA, R.-FROLÍK, J.-SIGL, J., 2003: Nálezy loštické keramiky ve východních Čechách - Funde der Lošticer Keramik in Ostböhmen, AH 28, 525-537.

ČEJKOVÁ, I.-ČEJKA, J.-MĚCHUROVÁ, Z., 1995: Chemical analysis of medieval graphitic pottery from Konůvky (Vyškov, Moravia) - Chemická analýza středověké tuhové keramiky z osady Konůvky u Vyškova na Moravě, ČNM CLXIV, řada přírodovědná, 17-23.

DROBNÁ, Z., 1957: Loštické poháry. K otázce jejich datování a slohového zařazení, Český lid XLIV, 98-107.

GOŠ, V., 1973: Slovanská osada v Mohelnici - Die Slawische Siedlung in Mohelnice, AR XXV, 371-379.

- 1980: K problematice výroby loštické keramiky. In: Sborník ze semináře Zkoumání výrobních objektů a technologií archeologickými metodami. Technické muzeum v Brně, 85-100. Brno.

- 1982: Charakteristika vývoje osídlení severní Moravy v 8.-15. stol. - Charakteristik der Besiedlung Nordmährens im 8.-15. Jahrhundert, AH 7, 157-162.

- 2007: Loštice. Město střredověkých hrnčířů. Opava. 
- 2012: Z Loštic až na konec světa. Nové objevy severomoravské středověké keramiky v západní Evropě, VVM LXIV, 11-17.

GOŠ, V.-NOVÁK, J., 1976: Počátky výroby loštické keramiky - Die Anfänge der Lošticer Keramikproduktion, AR XXVIII, 399-404.

GOŠ, V.-NOVÁK, J.-KAREL, J., 1975: Zaniklé sídliště v Rýmařově, ČSM B XXIV, 97-105.

GREGEROVÁ, M. a kol., 2010: Petroarcheologie keramiky v historické minulosti Moravy a Slezska. Masarykova univerzita, Brno.

LANG, A., 1961: Loštické poháry (Přehled dosavadních výzkumů), SM 6, 54-63.

MĚCHUROVÁ, Z., 1989: Keramika loštického typu z Konůvek (okr. Vyškov) - Die Keramik des Lošticer Typus aus Konůvky (Bez. Vyškov), ČMMZ LXXIV, 217-228.

MĚCHUROVÁ, Z.-ZALABÁK, P.-ČEJKA, J., 1992: Příspěvek k problematice tzv. loštické keramiky v souvislosti s rentgenovou fázovou analýzou vzorků z Konůvek (okr. Vyškov) - Beitrag zur Problematik dsg. Lošticer Keramik im Zusammenhang mit der Röntgenphasenanalyse der Bruchstücke aus Konůvky (Bez. Vyškov), ČMMZ LXXVII, 201-215.

MĚŘÍNSKÝ, Z., 1969: Přehled typů loštické keramiky, jejich vývoj a datování, VVM XXI, 89-105.

MICHNA, P. J., 1976: Loštický pohár na malbě ze 16. století? (Na okraj studia loštické keramiky), VVM XXVIII, 334-335.

NEKUDA, V.-REICHERTOVÁ, K., 1968: Středověká keramika v Čechách a na Moravě. Brno.

ŠAUROVÁ, D., 1971: Systematický výzkum zaniklé středověké vesnice Konůvky na Slavkovsku. In: Zaniklé středověké vesnice v ČSSR ve světle archeologických výzkumů. Díl I. Sborník prací přednesených na III. celostátním semináři o problematice zaniklých středověkých vesnic (Uherské Hradiště, Slovácké muzeum, 10.-13. 5. 1971), 169-201. Uherské Hradiště.

- 1980: Výrobní zařízení na keramiku v Konůvkách. In: Sborník ze semináře Zkoumání výrobních objektů a technologií archeologickými metodami, Technické muzeum v Brně, 101-112. Brno.

TOGNER, M., 1995: Moravská keramika a Hieronymus Bosch, Umění a řemesla, č. 1, 47-52.

\section{Zusammenfassung}

\section{Die Loschitzer Keramik aus der archäologischen Grabung auf der Brünner Burg Spielberg}

Die Loschitzer Ware zählt zweifellos zu den interessantesten Keramikgruppen überhaupt, besonders auch was das Mittelalter betrifft. Die in Loštice bei Mohelnice (Loschitz bei Müglitz) hergestellten Töpferwaren, Becher und Töpfe waren wegen ihres fast undurchlässigen, steinzeugähnlichen Materials und blasenartigen Aussehens der Oberfläche sehr beliebt. Ihre Produktion fällt in den Zeitraum vom Ende des 14. und in den Verlauf des 15. und 16. Jahrhunderts. Neueren Untersuchungen und naturwissenschaftlichen Analysen und Experimenten nach lag das Geheimnis dieses Materials in einer lehmhaltigen Töpfermasse mit beigemischtem feinen Graphit und vor allem in der absichtlichen Beimischung der Mineralien Pyrop oder Almandin aus der Gruppe der Granate. Die Loschitzer Töpfer überzogen die Gefäße dann mit einer Spezialglasur aus geschwemmtem Ziegellehm und eisenhaltiger weißer Tonerde, um ein violettartiges Aussehen zu erzielen. Die Brandtemperatur war relativ hoch und bewegte sich um die $1200 \mathrm{Grad}$, bei welcher die Kristalle des Granits ausschmolzen und sich die erwähnten Blasen bzw. Noppen bildeten, wodurch die gewünschte rissige, blasenartige Oberfläche erzielt wurde (Gregerová et al. 2010, 158-159). Die Form der Becher entwickelte sich von einfachen topfartigen Typen bis zur Form mit einem Ösenkranz unter dem Rand, deren Anzahl zwölf bis siebzehn erreichte. Die Loschitzer Becher gehörten sogar auch außerhalb der Grenzen der Länder Böhmens zu einem gesuchten und beliebten Tischgeschirr. Ein Exemplar mit zwölf Ösen und vergoldetem Deckel auf einem Fuß aus dem gleichen Metall wird in den Sammlungen des Kunstgewerbemuseums in Budapest als Bestandteil des Schatzes der Adelsfamilie Esterházy aus der Ära Corvins (zweite Hälfte 15. und erste Hälfte 16. Jhdt.) aufbewahrt. Dass man sich auch bis nach Westeuropa dieser Ware bewusst war, belegt die Darstellung eines Loschitzer Bechers auf Hieronymus Boschs Gemälde Der Garten der Lüste (Anfang 16. Jhdt.).

Es ist deshalb mehr als nur verständlich, dass der spezielle Charakter dieser Gruppe mittelalterlicher Keramik sehr bald das Interesse der Sammler und Experten weckte. Als ihre Ent- 
decker können der Baumeister K. Hladiš aus Loštice (1874) und der Olmützer Professer J. Havelka (1876) bezeichnet werden, die diese Keramik bei ihren Grabungen in Loštice erstmals entdeckten. Eine Diskussion über sie wurde vor allem in der deutschen Fachliteratur entfacht (genannt seien solche Persönlichkeiten wie R. Virchow oder J. Wankel - siehe detaillierter Drobná 1957, 98-99 - Anm. 5, 6; Lang 1961, 62 - Anm. 1-2). Von den modernen Wissenschaften war es vor allem die Kunstgeschichte, die sich dieser speziellen Keramik als erste angenommen haben (Drobná 1957, 98-107). Die Regionalgeschichte ließ dann nicht lange auf sich warten (Lang 1961, 54-62), jedoch erlebte die Loschitzer Keramik erst Ende der sechziger Jahre eine Bearbeitung aus archäologischer Feder (Nekuda-Reichertová 1968, 150-155; Měřínský 1969, 89-105). In den neunziger Jahren begann man damit, die Ursachen für ihr spezielles Aussehen zu suchen, jedoch wurde ihr erst Ende des ersten Jahrzehnts des 21. Jahrhunderts eine gründliche Erforschung durch naturwissenschaftliche Analysen und Experimente zuteil (Gregerová et al. 2010, 154-174), was teilweise durch die Gelder eines selbständigen Förderprojektes finanziert wurde. Im gleichen Jahrzehnt erlebt die Loschitzer Keramik auch eine monographische Bearbeitung (Goš 2007).

Es gibt folgende Grundtypen Loschitzer Keramik: Loschitzer Töpfe (grobe, größere, mit massivem Manschettenrand), Loschitzer Becher (topfartige und höhere schlanke) und Loschitzer Becher mit Ösen - zwei Varianten: a) schmale und schlanke, b) breitere und flache (Nekuda-Reichertová 1968, 151).

Bei einer archäologischen Grabung auf dem Brünner Spielberg wurden in drei Lagen (Nordflügel, nordöstlicher Schalenturm und Südflügel) insgesamt 88 Bruchstücke der Loschitzer Keramik entdeckt: 53 Fragmente von topfartigen Bechern, 28 Scherben von Töpfen (davon einer mit Henkel unterhalb des Halses) und das Mittelbruchstück eines glockenförmigen Deckels mit knopfartigem Griff. Die Fundumstände der Verfüllungsschichten liefern keine Präzisierung einer Datierung, die durch die Keramiktypen in die ältere Phase der Loschitzer Keramik gelegt wird, und zwar an das Ende des 14. und in das 15. Jahrhundert, eher in dessen erste Hälfte. In den nördlichen Lagen überwiegen unter den Loschitzer Fragmenten Trinkgefäße, Becher, der Südflügel barg lediglich Küchenkeramik, Bruchstücke von Töpfen. Es ist eine Frage der Analyse weiteren Materials, ob man anhand einer solchen Grundlage auf eine betriebliche Ausrichtung des untersuchten Raumes schließen kann.

PhDr. Zdeňka Měchurová, CSc., Moravské zemské muzeum, Zelný trh 6, 65937 Brno, zmechurova@mzm.cz 
